\title{
The spatiotemporal expression of multiple coho salmon ovarian connexin genes and their hormonal regulation in vitro during oogenesis
}

\author{
Yoji Yamamoto ${ }^{1,2^{*}}$, J Adam Luckenbach², Mollie A Middleton ${ }^{1,2}$ and Penny Swanson ${ }^{2}$
}

\begin{abstract}
Background: Throughout oogenesis, cell-cell communication via gap junctions (GJs) between oocytes and surrounding follicle cells (theca and granulosa cells), and/or amongst follicle cells is required for successful follicular development. To gain a fundamental understanding of ovarian GJs in teleosts, gene transcripts encoding GJ proteins, connexins (cx), were identified in the coho salmon, Oncorhynchus kisutch, ovary. The spatiotemporal expression of four ovarian $c x$ transcripts was assessed, as well as their potential regulation by follicle-stimulating hormone (FSH), luteinizing hormone (LH) and insulin-like growth factor 1 (IGF1).

Methods: Salmonid ovarian transcriptomes were mined for $c x$ genes. Four gene transcripts designated $c \times 30.9$, $c \times 34.3, c \times 43.2$, and $c \times 44.9$ were identified. Changes in gene expression across major stages of oogenesis were determined with real-time, quantitative RT-PCR (qPCR) and $c x$ transcripts were localized to specific ovary cell-types by in situ hybridization. Further, salmon ovarian follicles were cultured with various concentrations of FSH, LH and IGF1 and effects of each hormone on $c x$ gene expression were determined by qPCR.

Results: Transcripts for $c \times 30.9$ and $c \times 44.9$ were highly expressed at the perinucleolus (PN)-stage and decreased thereafter. In contrast, transcripts for $c \times 34.3$ and $c \times 43.2$ were low at the PN-stage and increased during later stages of oogenesis, peaking at the mid vitellogenic (VIT)-stage and maturing (MAT)-stage, respectively. In situ hybridization revealed that transcripts for $c \times 34.3$ were only detected in granulosa cells, but other $c x$ transcripts were detected in both oocytes and follicle cells. Transcripts for $c \times 30.9$ and cx44.9 were down-regulated by FSH and IGF1 at the lipid droplet (LD)-stage, whereas transcripts for $c \times 34.3$ were up-regulated by FSH and IGF1 at the LD-stage, and LH and IGF1 at the late VIT-stage. Transcripts for $c \times 43.2$ were down-regulated by IGF1 at the late VIT-stage and showed no response to gonadotropins.

Conclusion: Our findings demonstrate the presence and hormonal regulation of four different $c x$ transcripts in the salmon ovary. Differences in the spatiotemporal expression profile and hormonal regulation of these $c x$ transcripts likely relate to their different roles during ovarian follicle differentiation and development.
\end{abstract}

\section{Background}

The growth and development of oocytes and surrounding follicle cells (i.e., granulosa and theca cells) occurs in a highly orchestrated and mutually dependent manner. Communication between these different ovarian celltypes is dependent on direct signaling mediated by gap junctions (GJs), in addition to signaling via endocrine and/or paracrine pathways [1,2]. Gap junctions are

\footnotetext{
* Correspondence: yojifish@u.washington.edu

'School of Aquatic \& Fishery Sciences, University of Washington, Seattle, WA 98195, USA

Full list of author information is available at the end of the article
}

composed of an aggregate of intercellular membrane channels that allow the passage of molecules with a molecular weight of up to $1 \mathrm{kDa}$, including various second messengers such as cyclic AMP (cAMP) and inositol trisphosphate, and ions [3]. Each GJ channel is formed by two hemichannels (connexons), both of which are hexamers of connexin $(\mathrm{Cx})$ protein subunits $[4,5]$. Two connexons from adjacent cells dock to form a GJ channel. In mammals, numerous studies indicate that ovarian GJ communication is involved in regulation of the meiotic arrest of oocytes, steroidogenesis, and apoptosis [6-9]. In fishes, by contrast, detailed

\section{Ciomed Central}


information on the distribution, expression, and functions of ovarian GJs is largely unknown.

The few studies of ovarian GJs and $c x$ gene transcripts in fishes were performed during late stages of maturation, prior to ovulation. Final maturation of the fish ovarian follicle involves a number of events including luteinizing hormone ( $\mathrm{LH})$-dependent acquisition of oocyte maturational competence (OMC), LH induction of maturation-inducing hormone (MIH; typically either

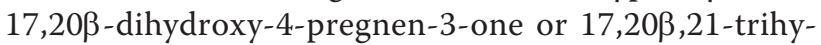
droxy-4-pregnen-3-one) synthesis, and MIH-dependent meiotic resumption [10]. Previous studies with Atlantic croaker, Micropogonias undulates, and red seabream, Pagrus major, used electron microscopy to show that the number of ovarian GJs (between granulosa cells and oocytes, and amongst granulosa cells) increased during LH-dependent acquisition of OMC [11-13]. Increases in ovarian GJs were also induced by insulin-like growth factor 1 (IGF1) treatment in red seabream [12]. Further, Yamamoto et al. $[14,15]$ found that culturing ovarian fragments with common GJ inhibitors prevented LHinduced acquisition of $\mathrm{OMC}$ in ayu, Plecoglossus altivelis, suggesting that ovarian GJ communication is essential for the LH-induced acquisition of OMC in this species. Thus, some ovarian GJs appear to be hormonally regulated and to have important roles during final maturation of the follicle in fishes. However, the function(s) and regulation of ovarian GJs during earlier stages of oogenesis, such as previtellogenic and vitellogenic stages, has not been studied.

So far, 21 human genes and 20 mouse $c x$ genes have been identified [16]. In addition, 37 putative $c x$ genes have been identified in the zebrafish genome [17]. Many $c x$ genes show tissue- or cell-type-specific expression patterns and most organs express more than one $c x$ [18]. According to Eastman's phylogenetic analysis, which was performed with the entire $C x$ family including human, mouse, and zebrafish $C x, c x$ genes can be classified into $\alpha, \beta$, and $\gamma$ groups, and potentially a fourth group containing human Cx62, mouse Cx57, and zebrafish Cx52.6 for example [17]. Studies in mammals have indicated that endocrine regulators of oogenesis such as follicle-stimulating hormone (FSH) and LH also regulate levels of $c x$ gene transcripts in the ovary [9]. For example, up-regulation of $c \times 43$ transcripts in response to $\mathrm{FSH}$ was reported in a rat granulosa cell line [19], while LH had an inhibitory effect on the expression of $c x 43$ in rat ovarian follicles in vitro [20]. Such gonadotropic regulation of $c x$ gene transcripts has also been reported in teleosts. In red seabream, purified native FSH increased $c \times 32.3$, while LH increased $c \times 31.5$ and $c \times 32.3$ transcripts during acquisition of OMC $[21,22]$. In addition, human chorionic gonadotropin (hCG) elevated $c \times 32.2$, but not $c \times 32.7$ transcripts in
Atlantic croaker during acquisition of OMC [23-25]. Thus, gonadotropins appear to regulate some ovarian $c x$ gene transcripts during oocyte maturation in teleosts. Meanwhile, the regulation of ovarian $c x$ gene transcripts by FSH, LH or IGF1 at earlier stages of oogenesis has not been examined.

The goals of this study were to identify and characterize ovarian $c x$ gene transcripts in coho salmon, Oncorhynchus kisutch, determine whether levels of $c x$ transcripts in the ovary change across stages of oogenesis, and to determine the subfollicular distribution of $c x$ transcripts in the ovary. Finally, we determined whether FSH, LH or IGF1 regulate $c x$ gene expression in previtellogenic and vitellogenic ovarian follicles. We used coho salmon as a model for this work because it is a semelparous species (spawns only once in its life and then dies) that exhibits synchronous follicle development. This unique reproductive trait allows for stagespecific analysis of a relatively homogenous clutch of ovarian follicles, which is not possible in iteroparous species. Furthermore, developmental profiles of FSH, LH, and IGF1 in the plasma are well characterized in salmon [26-29], giving biological relevance to any effects of these hormones on $c x$ gene expression during a specific stage of ovarian development.

\section{Methods}

\section{Animals and sampling}

Coho salmon were reared at the Northwest Fisheries Science Center (Seattle, WA, USA) in $10-15^{\circ} \mathrm{C}$ recirculated fresh water and fed a standard ration (0.6-1.0\% body weight/day) of a commercial diet (Skretting Feeds, Vancouver, BC, Canada). Lighting above the tanks was continually adjusted to match the natural photoperiod of Seattle $\left(48^{\circ} \mathrm{N}\right)$. Stages of oogenesis were determined and confirmed by histological analyses using Campbell et al. [27] and Nagahama [30] as guides.

Perinucleolus (PN)-stage follicles were sampled from age-1+ salmon in August. Cortical alveolus (CA)-stage, lipid droplet (LD)-stage, early vitellogenic (VIT)-stage (with oocytes containing yolk granules), mid VIT-stage (with oocytes containing yolk globules), and preovulatory, maturing (MAT)-stage follicles were sampled from age-2+ salmon in March, June, July, August and December, respectively. The germinal vesicles of oocytes in the MAT-stage were migrating (just before germinal vesicle break down). Prior to tissue sampling, fish were euthanized in buffered tricaine methanesulfonate $(0.05 \%$ MS222, Argent Chemical, Redmond, WA) and body and ovary weight were recorded. A piece of ovary was collected for histological analysis, and other pieces were frozen in liquid nitrogen for RNA isolation and mRNA analyses. Fish used in the experiments were reared and handled according to the policies and guidelines of the 
University of Washington Institutional Animal Care and Use Committee (IACUC Protocol \#2313-09).

\section{RNA isolation}

For the across-stage comparisons of transcript levels, approximately 40-100 mg (wet wt.) pieces of ovarian tissue were homogenized in $1 \mathrm{ml}$ Tri-Reagent/sample (Molecular Research Center, Cincinnati, $\mathrm{OH}$ ) using a TissueLyser II (QIAGEN, Valencia, CA) and total RNA was isolated according to the manufacturer's instructions. Because of the large size of MAT-stage follicles (130-140 mg/follicle), 5 follicles/fish were homogenized in $7 \mathrm{ml}$ of Tri-Reagent. For culture experiment 1 (see below), 40-70 mg of cultured ovarian tissue from each well was homogenized with $1 \mathrm{ml}$ of Tri-Reagent. For culture experiment 2, one cultured follicle (late VITstage, $40-80 \mathrm{mg} /$ follicle) from each well was homogenized in $1 \mathrm{ml}$ of Tri-Reagent. Isolated total RNA samples were then diluted to $\sim 250 \mathrm{ng} \mathrm{RNA} / \mathrm{ml}$ in nucleasefree water.

Total RNA samples were then DNase treated using the Turbo DNA-Free kit's "rigorous" protocol (Applied Biosystems/Ambion, Austin, TX) where the amount of DNase enzyme and treatment time were doubled. RNA yields and quality were assessed by NanoDrop (ND1000 Spectrophotometer; NanoDrop Technologies, Rockland, DE) and gel electrophoresis.

For the across-stage comparisons, mRNA was further isolated from total RNA samples to mitigate issues associated with comparing ovarian follicles during different stages of oogenesis, which may be dramatically different in size and RNA composition [31]. mRNA was isolated from $200 \mathrm{mg}$ of total RNA/sample using the MicroPoly (A)Purist kit (Ambion, Austin, TX). As in vitro culture experiments were done with ovarian follicles of the same stage, total RNA was used for cDNA synthesis (see below).

\section{cDNA synthesis}

For each sample, $500 \mathrm{ng}$ of total RNA (for culture experiments) or $50 \mathrm{ng}$ of mRNA (for across-stage comparisons of $c x$ transcripts) was reverse transcribed in a 10- $\mu l$ reaction with the Superscript II kit (Invitrogen, Carlsbad, CA). Other necessary components for reverse transcription (RT), such as random primers and RNase inhibitor, were purchased from Promega (Madison, WI). Negative control reactions were performed without the addition of the RT enzyme for a subset of the RNA samples.

\section{Identification of coho salmon connexins}

To identify coho salmon ovarian $c x$ gene transcripts, we conducted searches within our previous coho salmon ovarian cDNA libraries (Luckenbach et al. unpublished data) and located partial cDNAs for gene transcripts we later named $c \times 30.9, c x 34.3$, and $c x 44.9$. Partial cDNAs for $c \times 30.9$ and $c \times 44.9$ showed high homology to Atlantic salmon, Salmo salar, gap junction beta 6 protein (Gjb6, GenBank accession number; NM_001140280.1) and rainbow trout, Oncorhynchus mykiss, $c x$ sequences (Accession numbers: TC152456 and TC137376) in the DFCI R. trout gene index database [32], respectively. Primers to amplify the complete coding sequence (CDS) of these two $c x$ genes were designed within these salmonid fish sequences. The complete CDS for coho salmon cx34.3 was determined by constructing a contig from several coho salmon expressed sequence tags (ESTs) and then the entire sequence was confirmed by PCR. Although we did not find $c x 43.2$ in our salmon ovarian cDNA libraries, rainbow trout $c x 43$ (GenBank accession number DQ204869.1), which is a homologue of coho salmon $c x 43.2$, had been previously studied in the trout ovary [33]. Thus, we cloned $c \times 43.2$ from the coho salmon ovary using primers designed from the trout cDNA sequence.

The primers for cloning each salmon $c x$ are shown in Table 1. The RT-PCRs for cloning were carried out for 35 cycles as follows: $94^{\circ} \mathrm{C}$ for $30 \mathrm{~s}$ for denaturing, $52^{\circ} \mathrm{C}$ for $30 \mathrm{~s}$ for annealing and $72^{\circ} \mathrm{C}$ for $90 \mathrm{~s}$ for extension. The RT-PCR reactions consisted of 18 ng cDNA template (based on the mRNA loaded into the RT reactions), which was synthesized using mRNA of MATstage ovary. We used SuperTaq ${ }^{\mathrm{TM}}$ Polymerase (Ambion) according to the manufacturer's instructions. The resultant PCR products of expected size were inserted into a pGEM-T Easy vector (Promega, Madison, WI) or $\mathrm{pCR}^{\circledR}$ $\mathrm{XL}^{-T O P O}{ }^{\circledR}$ vector (Invitrogen), and completely sequenced on both DNA strands with an ABI PRISM 3100-Avant Genetic Analyzer.

\section{Quantitative PCR}

For $c x$ gene transcript analyses, we performed real-time quantitative RT-PCR (qPCR). The qPCR procedure was similar to that previously reported by Luckenbach et al $[31,34]$. The sequences of gene-specific primers (GSP) for qPCR are listed in Table 1. Reactions consisted of $1 \times$ Power SYBR Green PCR master mix (ABI), $150 \mathrm{nM}$ of each gene-specific forward and reverse primer and $0.05 \mathrm{ng}$ (based on the mRNA loaded into the RT reactions, for the across-stage comparisons of $c x$ transcripts) or $0.5 \mathrm{ng}$ (based on the total RNA loaded into the RT reactions, for culture experiment 1 and 2) of cDNA templates. Triplicate standard curve samples generated from a serial dilution of pooled mRNA from ovaries of six randomly selected previtellogenic coho salmon (for the across-stage comparisons of $c x$ transcripts), or pooled total RNA from six randomly selected ovaries after being cultured $36 \mathrm{~h}$ with hormones (for culture experiment 1 and 2) were included in each 
Table 1 List of primers used for cloning and quantitative RT-PCR

\begin{tabular}{|c|c|c|c|c|}
\hline Step & Gene name & Strand & Sequence & Product size (bp) \\
\hline \multirow[t]{2}{*}{ cloning } & $c \times 30.9$ & Sense & 5'-GAAATTCCGAGGAGGTGGTC-3' & 1,088 \\
\hline & & Antisense & 5'-GCATGTTTGTCCAGGACTAC-3' & \\
\hline \multirow[t]{2}{*}{ cloning } & cx34.3 & Sense & 5'-CTGAGAGACTGAGAGCTCCAAAC-3' & 1,038 \\
\hline & & Antisense & 5'-AGACTGGCATGCGAATCATTG-3' & \\
\hline \multirow[t]{2}{*}{ cloning } & $c \times 43.2$ & Sense & 5'-TCAAGAAGTGACGGAGAAAG-3' & 1,278 \\
\hline & & Antisense & 5'-GTACTCTCTGTTCTCTGGCA-3' & \\
\hline \multirow[t]{2}{*}{ cloning } & cx44.9 & Sense & 5'-AGCCTTAAAGAGCTGAGAGG-3' & 1,273 \\
\hline & & Antisense & 5'-CGAGCAGGCATTAAGCAGGA-3' & \\
\hline $\mathrm{qPCR}^{*}$ & $c \times 30.9$ & Antisense & 5'-GGCTGGTGGAGTGTTTGTC-3' & 99 \\
\hline \multirow[t]{2}{*}{ qPCR } & cx34.3 & Sense & 5'-ACTACCTGTATGGCTTCACCCT-3' & 284 \\
\hline & & Antisense & 5'-CTGGATCATCTGGTCTTTGTTC-3' & \\
\hline \multirow[t]{2}{*}{$\mathrm{qPCR}$} & $c \times 43.2$ & Sense & 5'-ATGGCTGTTCCTCTCCCACT-3' & 121 \\
\hline & & Antisense & 5'-CAGTTITGCTCGTTGGCTTG-3' & \\
\hline \multirow[t]{2}{*}{$\mathrm{qPCR}$} & $c \times 44.9$ & Sense & 5'-GTGACAGAAGGCTCTGTGAAG-3' & 305 \\
\hline & & Antisense & 5'-ACACCGAGATGGAGAATCTC-3' & \\
\hline
\end{tabular}

${ }^{*}$ qPCR for $c \times 30.9$ was performed using $c \times 30.9$ cloning primer with the antisense qPCR primer for $c \times 30.9$.

plate. Results were analyzed using the relative standard curve method according to the manufacturer's instructions. Negative controls were included in each plate and consisted of either no RNA template (no template control, NTC) or RNA template that was not reverse transcribed (no amplification control, NAC). NACs reveal possible genomic DNA contamination in the RNA preparations. Negative control samples showed either no detectability or negligible values ( $>10$ cycle separation from experimental samples). A melt curve analysis was included for each target gene to ensure that a single product was amplified, and in addition, a qPCR product was sequenced to verify that the target was successfully amplified.

Previous work in coho salmon showed that normalization of qPCR data to elongation factor-1 alpha (ef1a) generated results that best reflected transcript abundance on a per follicle basis in coho salmon follicle when comparing across different stages of oogenesis [31]. Therefore expression data for the $c x$ transcripts were normalized to ef1a in this study. The levels of ef1a transcripts were stable (i.e., not significantly different) for the in vitro experiments and across four of the five stages (PN- to VIT-stage) of oogenesis included in the across-stage comparison (see Figure 2A inset). Due to the observed increase in efla at the MAT-stage, data for the $c x$ genes were assessed both normalized to efla and un-normalized. Results overall for the two approaches were statistically very similar and therefore efla normalized data are shown for the $c x$ transcripts. The primers for efla were the same as previously reported [31].

\section{In situ hybridization}

Transcripts for all four $c x$ gene transcripts were localized by in situ hybridization (ISH) in PN-, CA-, LD-, early VIT- and MAT-stage ovarian follicles. However, ISH was technically difficult to perform with MAT-stage follicles due to the large amount of yolk present in the oocytes, and results are therefore not shown for this stage.

The cDNA fragments containing the entire CDS that is, nucleotides $1-1,088,1-1,038,1-1,278$, and 1 1,273 for $c x 30.9, c x 34.3, c x 43.2$, and $c x 44.9$, respectively - were used as templates for the synthesis of RNA probes. Sense and antisense RNA probes for each $c x$ were transcribed in vitro using digoxigenin-labeled UTP (Roche Diagnostics, Basel, Switzerland) and T7 RNA polymerase (New England Biolabs, Ipswich, MA). To prepare tissues for ISH, ovarian samples were fragmented into several pieces and fixed in $4 \%$ paraformaldehyde (Electron Microscopy Sciences, Hatfield, PA) with gentle shaking at room temperature for 16-36 h. Fixed ovaries were rinsed three times with phosphate buffered saline (PBS) over $45 \mathrm{~min}$, sequentially dehydrated through a methanol series $(25 \%, 50 \%$, and $75 \%$ methanol/PBS), and stored in $100 \%$ methanol at $-20^{\circ} \mathrm{C}$ until use.

A portion of each sample was embedded in paraffin wax and cut into $5-\mu \mathrm{m}$ serial sections using a microtome. Paraffin sections were mounted on SUPERFROST $^{\circledR}$ Plus microscope slides (Thermo Scientific, Portsmouth, NH), dewaxed, and dehydrated by immersion in a xylene-ethanol series. Slides were either stained with hematoxylin and eosin (VECTOR LABORATORIES, Burlingame, CA) or processed for ISH with DIG-labeled RNA probes. Sections for ISH were permeabilized, post-fixed with $4 \%$ paraformaldehyde at room temperature for $20 \mathrm{~min}$, and treated with $5 \mathrm{mg} / \mathrm{ml}$ proteinase $\mathrm{K}$ at $37^{\circ} \mathrm{C}$ for $10 \mathrm{~min}$. The sections were subsequently acetylated, and then incubated with a 
hybridization mixture of $0.0125-0.2 \mathrm{mg} / \mathrm{ml}$ RNA probe, $50 \%$ formamide, $2 \times$ saline-sodium citrate (SSC) $(\mathrm{pH}$ 4.5), $50 \mathrm{mg} / \mathrm{ml}$ transfer RNA (tRNA), $50 \mathrm{mg} / \mathrm{ml}$ heparin, $1 \%$ sodium dodecyl sulfate (SDS), and $10 \%$ dextran sulfate. After hybridization at $65^{\circ} \mathrm{C}$ for $16 \mathrm{~h}$, the sections were washed as follows: twice in $5 \times \mathrm{SSC} / 50 \%$ formamide at $65^{\circ} \mathrm{C}$ for $30 \mathrm{~min}$, three times in $2 \times \mathrm{SSC} / 50 \%$ formamide at $65^{\circ} \mathrm{C}$ for $30 \mathrm{~min}$, and once in $1 \times \mathrm{SSC} / 25 \%$ formamide: $1 \times$ Tris buffered saline containing $0.1 \%$ Tween-20 (TBST) at room temperature for $30 \mathrm{~min}$. Unbound probes were digested using $20 \mathrm{mg} / \mathrm{ml}$ RNase A to reduce background signals. After RNase digestion at $37^{\circ} \mathrm{C}$ for $30 \mathrm{~min}$, the sections were placed in NTE buffer $(500 \mathrm{mM} \mathrm{NaCl}, 10 \mathrm{mM}$ Tris- $\mathrm{HCl} \mathrm{pH} 8.0,1 \mathrm{mM}$ ethylenediamine tetraacetic acid) at $37^{\circ} \mathrm{C}$ for $5 \mathrm{~min}$ before being washed three times in $0.5 \times \mathrm{SSC}$ at $65^{\circ} \mathrm{C}$ for $20 \mathrm{~min}$, three times in $1 \times \mathrm{TBST}$ at room temperature for $5 \mathrm{~min}$, and in blocking solution (1×TBST and 2\% Blocking Reagent; Roche Diagnostics) at room temperature for $1 \mathrm{~h}$. Subsequently, the sections were incubated with the Fab fragment of an anti-DIG-alkaline phosphatase-conjugated antibody (Roche Diagnostics) diluted 1:2000 with blocking solution at $8^{\circ} \mathrm{C}$ for $16 \mathrm{~h}$. Finally, each section was rinsed three times in TBST containing $1 \mathrm{mM}$ Levamisole (Sigma-Aldrich, St. Louis, MO) for 5 min. The sections were then incubated in a NTMT solution $(100 \mathrm{mM} \mathrm{NaCl}, 100 \mathrm{mM}$ Tris- $\mathrm{HCl} \mathrm{pH}$ 9.5, 50 $\mathrm{mM} \mathrm{MgCl}, 0.1 \%$ Tween 20, $1 \mathrm{mM}$ Levamisole) containing $0.0035 \%$ nitroblue tetrazolium (NBT; Roche Diagnostics) and $0.0018 \%$ 5-bromo-4-chloro-3-indolyl phosphate (BCIP; Roche Diagnostics) at room temperature in the dark. After the color reaction had occurred, the slides were sealed with CYTOSEAL ${ }^{\mathrm{TM}}$ XYL (Thermo Scientific).

\section{Ovarian cultures}

Culture experiments were conducted as described previously $[34,35]$ to assess the effects of various hormones on ovarian $c x$ gene expression. Animals were anaesthetized as above and the ovaries were removed, weighed, and held in chilled Leibovitz L-15 medium (Invitrogen, Carlsbad, CA) prior to dissection of follicles. Highlypurified coho salmon FSH and LH used in the experiments were obtained according to Swanson et al. [36]. Human recombinant IGF1 was purchased from Bachem (Torrance, CA). All hormones were solubilized in 20 $\mathrm{mM}$ phosphate buffered saline supplemented with $0.2 \%$ bovine serum albumin (BSA, RIA grade; Sigma-Aldrich) and then dissolved directly in the culture medium. Ovarian tissue fragments from a fish were distributed into 24-well polystyrene culture plates so that each treatment received one tissue fragment from each of the fish. Each treatment therefore included ovarian follicles from 6 different fish. Culture wells contained $1 \mathrm{ml}$ of L-
15 medium supplemented with $0.2 \%$ BSA and tissues were pre-incubated at $14^{\circ} \mathrm{C}$ for $2 \mathrm{~h}$ with gentle orbital shaking at $100 \mathrm{rpm}$. After the pre-incubation, the medium was removed and replaced with fresh L-15 medium containing either no hormone or hormone as described below. Time $0 \mathrm{~h}$ ovaries (initial) were collected and snap frozen in liquid nitrogen just after the pre-incubation for later RNA isolation.

\section{Culture experiment 1; FSH and IGF1 effects on ovarian $c x$ genes}

This experiment was conducted in mid-June 2010 with LD-stage ovaries, because previous studies with coho salmon showed that levels of plasma FSH begin to increase in early spring (generally, Feb-May) and reach peak levels in late summer (Aug-Sept) [26]. The mean fish body weight $( \pm$ SEM) was $595.9 \pm 29.0 \mathrm{~g}$, fork length was $36.2 \pm 0.7 \mathrm{~cm}$, paired ovary weight was 6.42 $\pm 0.62 \mathrm{~g}$, and gonadosomatic index (GSI; gonad weight/ body weight*100) was $1.07 \pm 0.06 \%$. Approximately 40 $70 \mathrm{mg}$ of ovarian tissue/well was incubated with or without hormones. FSH concentrations were 0 (control), $10,50,100$, or $500 \mathrm{ng} / \mathrm{ml}$ and IGF1 concentrations were 0 (control), 1,10 , or $100 \mathrm{nM}$. Cultures were maintained for $36 \mathrm{~h}$ based on results of a previous time course study [34], which demonstrated that several ovarian genes affected by FSH showed a difference from controls at this time point. After the experiment, ovarian tissues were dabbed on lens paper to remove excess liquid, weighed, and snap frozen in liquid nitrogen for later RNA isolation.

\section{Culture experiment 2; LH and IGF1 effects on ovarian CX genes}

This experiment was conducted in early October 2010 with late VIT-stage ovaries, because previous studies with coho salmon showed that plasma LH levels begin to increase slightly in fall (generally Oct/Nov in our hatchery), prior to the ovulatory surge [26]. The mean fish body weight $( \pm$ SEM) was $1152.8 \pm 90.9 \mathrm{~g}$, fork length was $44.0 \pm 0.6 \mathrm{~cm}$, paired ovary weight was 110.3 $\pm 20.3 \mathrm{~g}$, and GSI was $9.1 \pm 1.1 \%$. Because of the large size of late VIT-stage follicles $(40-80 \mathrm{mg} /$ follicle), three follicles/well were cultured with or without hormones for $36 \mathrm{~h}$. The LH concentrations were 0 (control), 10, 50,100 , or $500 \mathrm{ng} / \mathrm{ml}$ and IGF1 concentrations were the same as in experiment 1 .

\section{Measurement of medium E2 levels}

In salmon, both gonadotropins have been shown to stimulate production of estradiol-17ß (E2) by ovarian follicles in vitro [34,37] and E2 had a biphasic effect on transcripts for ovarian $c x$ genes in Atlantic croaker [25]. Furthermore, IGF1 can modulate aromatase activity [38]. Thus, it is informative to know how these hormones affected ovarian E2 production, which in turn 
may have influenced $c x$ gene expression. After the 36-h cultures, the medium from each well was collected and stored at $-80^{\circ} \mathrm{C}$ until later E2 measurement. Samples were heat treated at $80^{\circ} \mathrm{C}$ for $1 \mathrm{~h}$, centrifuged at 15,700 $\times \mathrm{g}$ for $7 \mathrm{~min}$, and supernatants were transferred to a fresh tube [34]. Medium E2 levels were then determined by radioimmunoassay (RIA) as previously described [39].

\section{Statistical analysis}

The across-stage $c x$ gene expression data and in vitro ovarian incubation data were subjected to one-way analysis of variance followed by Tukey multiple mean comparison tests. Data were $\log _{10}$ transformed when necessary to meet normality and equal variance assumptions and reported as means \pm SEM. Results for initial and control samples from the ovarian incubation experiments were compared by unpaired t-tests. All statistical analyses were conducted using the SPSS 11.0 microcomputer software package (SPSS, Chicago, IL).

\section{Results}

Isolation and characterization of coho salmon cx cDNAs cDNAs encoding 4 salmon $c x$ genes were obtained with GSPs (Table 1). The $c x 30.9$ cDNA (GenBank Accession No. HQ315553) was 1,088 bp and 272 aa, $c \times 34.3$ (HQ315554) was $1,038 \mathrm{bp}$ and 298 aa, $c \times 43.2$ (HQ315555) was $1,278 \mathrm{bp}$ and 383 aa, and $c \times 44.9$ (HQ315556) was 1,273 bp and 399 aa. From the predicted $\mathrm{Cx}$ amino acids sequences, the expected molecular weights of the proteins would be 30.9, 34.3, 43.2, and $44.9 \mathrm{kDa}$. Therefore, following the nomenclature system proposed by Beyer et al. [40], we named the genes accordingly. The homologies of amino acid sequences among the coho salmon $c x$ genes were less than $55 \%$. NCBI protein BLAST [41] searches revealed that coho salmon $c x 30.9, c x 34.3, c x 43.2$ and $c x 44.9$ sequences had the highest homology with Atlantic salmon Gjb6 (94.5\%), zebrafish, Danio rerio, Cx34.5 (76.5\%; GenBank accession number; NP_001025371.1), rainbow trout Cx43 (99.7\%), and ayu Cx44.2 (72.5\%; GenBank accession number; DQ487732.1), respectively. The amino acid sequences obtained for the four $c x$ gene transcripts included all the characteristic features of $\mathrm{Cx}$ family proteins, including two $c x$ consensus sequences, $C(D, N)$ TXQPGCX 2 VCYD and $\mathrm{CX}_{3 \text { or } 4} \mathrm{PCX}_{3}(\mathrm{~L}, \mathrm{I}, \mathrm{V}, \mathrm{M})(\mathrm{D}, \mathrm{E}, \mathrm{N})$ $\mathrm{C}(\mathrm{F}, \mathrm{Y})(\mathrm{L}, \mathrm{I}, \mathrm{V}, \mathrm{M})(\mathrm{S}, \mathrm{A})(\mathrm{K}, \mathrm{R}) \mathrm{P}$, in the predicted extracellular loops (data not shown). Hydropathy analysis revealed that the coho salmon $\mathrm{Cx}$ proteins encoded by these genes would contain four hydrophilic domains and five hydrophobic domains that are typical of known Cx proteins (data not shown). Furthermore, phylogenetic analysis, was performed by the neighbor-joining method with ClustalX multiple alignment algorithm using NJPLOT software $[42,43]$. This revealed that
Cx34.3 and Cx43.2 are $\alpha$-type, Cx30.9 is a $\beta$-type, and Cx44.9 is a $\gamma$-type $c x$ (Figure 1 ). The zebrafish and mouse Cxs in our analysis were classified in the same groups as previously reported [17].

\section{Ovarian cx transcript levels during oogenesis}

The levels of transcripts for $c x 30.9$ and $c x 44.9$ showed a similar profile across-stages of oogenesis where levels were highest at the PN-stage and steadily declined thereafter (Figure 2A and 2D). Levels of transcripts for cx34.3 were lowest at the PN-stage, increased leading up to vitellogenesis, and reached peak levels by the mid VIT-stage (Figure 2B). Levels of $c x 43.2$ transcripts remained low during previtellogenic stages, increased during vitellogenesis and peaked by the MAT-stage (Figure 2C).

\section{Intraovarian distribution of cx mRNAs}

The results of ISH for each $c x$ are shown in Table 2 and Figure 3. ISH using $\mathrm{PN}$-stage ovaries indicated that cx30.9 (Table 2 and Figure 3B) and cx44.9 (Table 2 and Figure 3E) transcripts were present in oocytes and follicle cells. As follicle cell layers at the PN-stage were very thin, it was not possible to distinguish whether both the theca and granulosa cells expressed these $c x$ transcripts (Figure 3B and 3E). The signals for $c \times 30.9$ and $c \times 44.9$ transcripts were also detected in oocytes from the CAto VIT-stage, however the signals in follicle cells were not detected in the CA-stage or thereafter (Table 2). ISH indicated that $c \times 34.3$ mRNA was only expressed in the follicle cells (only granulosa cells through the CAto the VIT-stage, Table 2 and Figure $3 \mathrm{H}$ ). Transcripts for $c x 43.4$ were localized to follicle cells (both theca and granulosa cells at the CA-, LD- and early VIT-stages) and within oocytes (Table 2 and Figure 3K).

\section{Culture experiment 1: Effects of FSH and IGF1 on ovarian cx gene expression}

In LD-stage follicles, FSH significantly reduced transcript levels for $c \times 30.9$ and $c \times 44.9$ in a concentrationdependent manner (Figure $4 \mathrm{~A}$ and $4 \mathrm{D})$. In contrast, transcripts for $c x 34.3$ increased in a concentrationdependent manner, reaching a more than 8-fold maximum elevation relative to control when treated with 500 ng FSH/ml (Figure 4B). FSH did not affect $c x 43.2$ levels at any concentration (Figure 4C). IGF1 had effects similar to FSH on ovarian $c x$ expression. Transcripts for $c x 30.9$ and $c x 44.9$ were suppressed in a concentrationdependent manner, but were only significantly downregulated relative to controls at the highest concentration, $100 \mathrm{nM}$ IGF1 (Figure 4E and 4H). Transcripts for cx43.2 were significantly suppressed by 100 nM IGF1 relative to controls (Figure 4G). In contrast, IGF1 elevated transcripts for $c x 34.3$ in a concentration- 


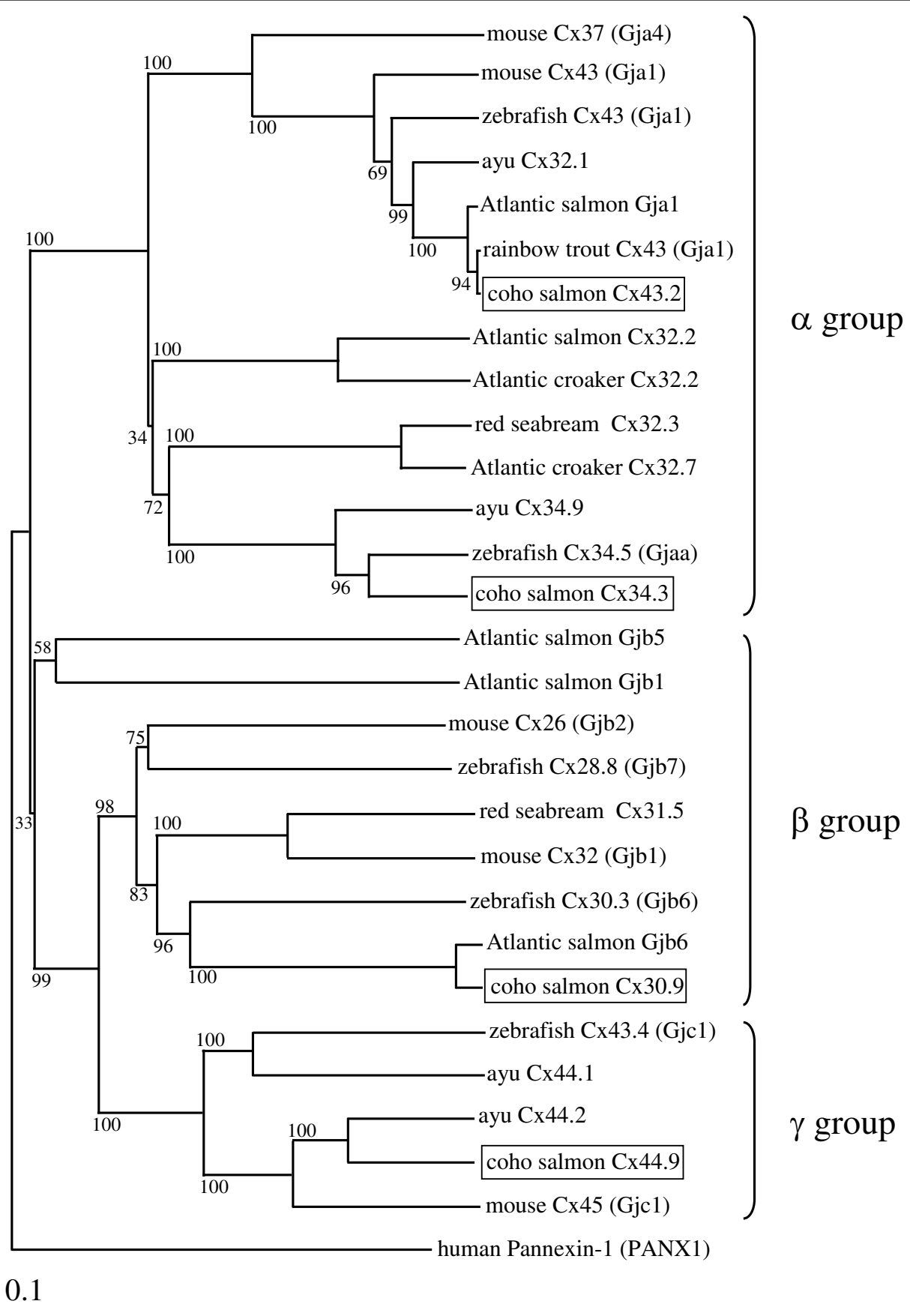

Figure 1 Phylogenetic relationship between coho salmon and other known Cx proteins. A neighbor-joining (NJ) distance tree comparing full-length amino acid sequences is shown. Bootstrap values (\%) are shown for the NJ analyses. The GenBank accession numbers of the aligned deduced amino acid sequences of Cx proteins are as follows: Atlantic croaker Cx32.2 (L31542.1) and Cx32.7 (L31541.1), Atlantic salmon Cx32.2 (BT049836.1), gap junction protein alpha 1; Gja1 (BT059188.1), gap junction protein beta 1; Gjb1 (BT044946.1), gap junction protein beta 5; Gjb5 (BT057893.1) and gap junction protein beta 6; Gjb6 (NM_001140280.1), ayu Cx32.1 (DQ487733.1), Cx34.9 (DQ487730.1), CX44.1 (DQ487731.1) and Cx44.2 (DQ487732.1), mouse, Mus musculus, Cx26 (also known as gap junction protein beta 2; Gjb2, AAA37276.1), Cx32 (also known as gap junction protein beta 1; Gjb1, AAA37296.2), Cx37 (also known as gap junction protein alpha 4; Gja4, NP 032146.1), Cx43 (also known as gap junction protein alpha 1; Gja1, NM_010288.3) and Cx45 (also known as gap junction protein gamma 1; Gjc1, NM_008122.3), rainbow trout Cx43 (also known as gap junction protein alpha 1; Gja1, DQ204869.1), red seabream Cx31.5 (AB037933.1) and Cx32.3 (AB048251.1), and zebrafish Cx28.8 (also known as gap junction protein beta 7; Gjb7, NP_001020715.1), Cx30.3 (also known as gap junction protein beta 6; Gjb6, NP_997990.2), Cx34.5 (also known as gap junction protein alpha a; Gjaa, NP_001025371.1), Cx43 (also known as gap junction protein alpha 1; Gja1, NP_571113.1), and CX43.4 (also known as gap junction protein gamma 1; Gjc1, AAB36619.1). Human, Homo sapiens, Pannexin-1 (PANX1; NP_056183.2) was used as the outgroup. 


\section{(A)}

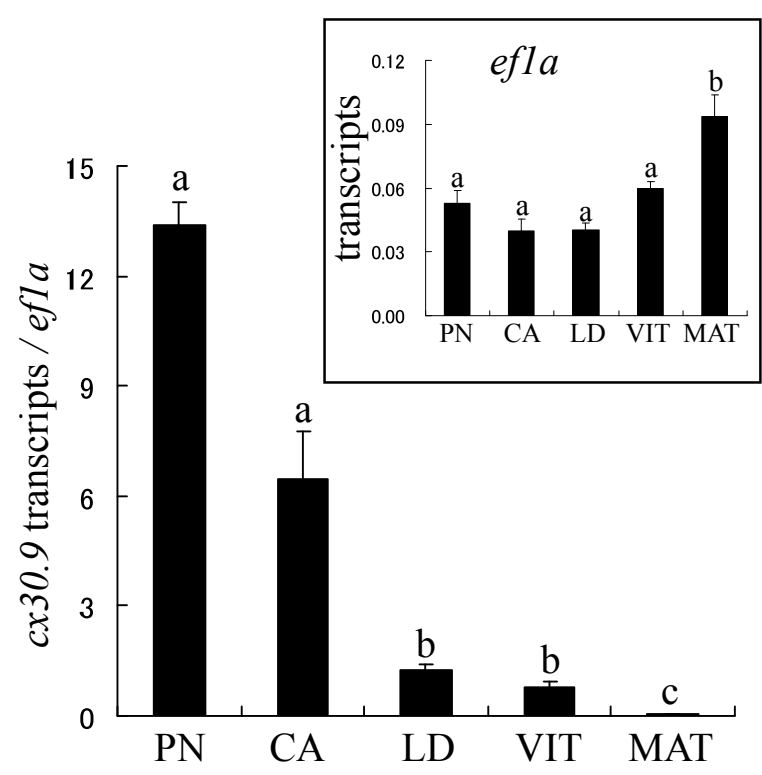

(C)
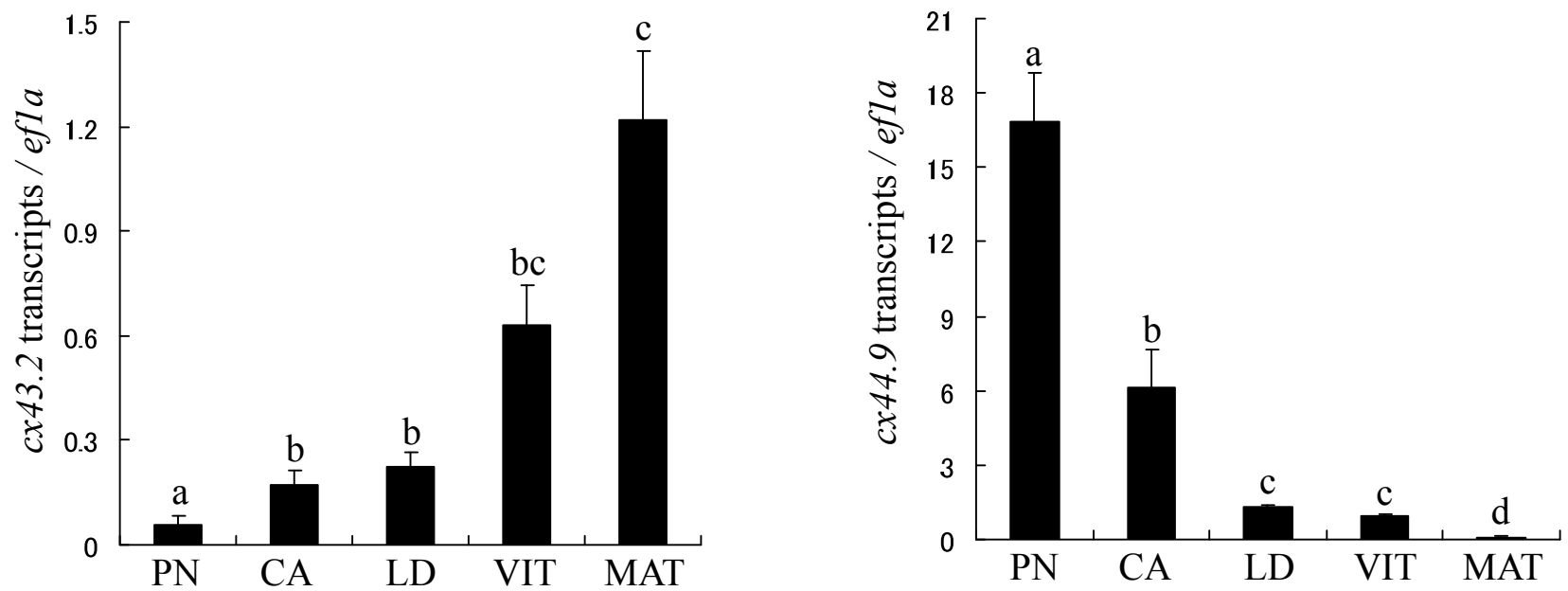

Figure 2 Temporal expression patterns of four $c x$ mRNAs during oogenesis. The expression levels of $c \times 30.9$ (A), $c \times 34.3$ (B), $c \times 43.2$ (C), and cx44.9 (D) were normalized to ef1a (inset of panel A). PN, perinucleolus stage follicles; CA, cortical alveolus stage follicles; LD, lipid droplet stage follicles; VIT, mid-vitellogenic stage follicles; MAT, preovulatory, maturing stage follicles. Bars not sharing the same letter are significantly different $(P<0.05 ; n=4 /$ group of PN-, CA-, LD-, and VIT-stages, $n=3$ /group of MAT-stage, mean \pm SEM).

dependent manner reaching a more than 13 -fold maximum increase relative to control when treated with 100 nM IGF1 (Figure 4F).

Levels of $c x$ transcripts in LD-stage ovaries cultured in control medium for $0 \mathrm{~h}$ (initial) and $36 \mathrm{~h}$ showed different patterns. Transcripts for $c \times 30.9$ (Figure 4A) and cx44.9 (Figure 4D) did not change significantly between initial and control. Transcripts for $c \times 34.3$ decreased dramatically reaching a more than 64-fold maximum decline by $36 \mathrm{~h}$ (Figure 4B). In contrast, transcripts for $c x 43.2$ increased more than 3 -fold relative to initial levels after $36 \mathrm{~h}$ in culture (Figure 4C). 
Table 2 Spatial expression profiles of $c x$ transcripts in the coho salmon ovary

\begin{tabular}{cccccc}
\hline$c \boldsymbol{x}$ & Localization & PN-stage & CA-stage & LD-stage & VIT-stage \\
\hline cx30.9 & oocyte & + & + & $\mathrm{w}$ & $\mathrm{W}$ \\
& follicle cells & + & $\mathrm{G}: \mathrm{x}, \mathrm{T}: \mathrm{x}$ & $\mathrm{G}: \mathrm{x}, \mathrm{T}: \mathrm{x}$ & $\mathrm{G}: \mathrm{x}, \mathrm{T}: \mathrm{x}$ \\
cx34.3 & oocyte & $\mathrm{x}$ & $\mathrm{x}$ & $\mathrm{x}$ & $\mathrm{x}$ \\
& follicle cells & + & $\mathrm{G}:+, \mathrm{T}: \mathrm{x}$ & $\mathrm{G}:+, \mathrm{T}: \mathrm{x}$ & $\mathrm{G}:+, \mathrm{T}: \mathrm{x}$ \\
cx43.2 & oocyte & + & + & + & + \\
& follicle cells & + & $\mathrm{G}:+, \mathrm{T}:+$ & $\mathrm{G}:+, \mathrm{T}:+$ & $\mathrm{G}:+, \mathrm{T}:+$ \\
cx44.9 & oocyte & + & + & $\mathrm{W}$ & $\mathrm{W}$ \\
& follicle cells & + & $\mathrm{G}: \mathrm{x}, \mathrm{T}: \mathrm{x}$ & $\mathrm{G}: \mathrm{x}, \mathrm{T}: \mathrm{x}$ & $\mathrm{G}: \mathrm{x}, \mathrm{T}: \mathrm{x}$
\end{tabular}

Each mark indicates signal levels of $c x$ s by ISH. + , signal; $w$, weak signal; $x$, signal undetectable. PN, perinucleolus stage follicles; $\mathrm{CA}$, cortical alveoli stage follicles; LD, lipid droplet stage follicles; VIT, early-vitellogenic stage follicles. G, granulosa cells; $T$, theca cells.

\section{Culture experiment 2: Effects of LH and IGF1 on ovarian cx gene expression}

In late VIT-stage follicles, LH increased the level of transcripts for $c \times 34.3$ in a concentration-dependent manner, reaching a more than 11 -fold increase relative to control when treated with $500 \mathrm{ng} \mathrm{LH} / \mathrm{ml}$ (Figure 5A). In contrast, LH did not affect transcripts for $c x 43.2$ at any concentration tested (Figure 5B). IGF1 elevated transcripts for $c \times 34.3$ in a concentration-dependent manner reaching a more than 8 -fold maximum increase relative to control when treated with 100 nM IGF1 (Figure $5 \mathrm{C}$ ). In contrast, IGF1 suppressed transcripts for cx43.2 in a concentration-dependent manner, but this was only significant with 100 nM IGF1 (Figure 5D). Transcripts for $c \times 30.9$ and $c \times 44.9$ were very low at the late-VIT stage, and neither LH nor IGF1 altered levels of these transcripts at any concentration tested (data not shown).

Levels of transcripts for each $c x$ gene in late VIT-stage ovaries cultured in control medium for $0 \mathrm{~h}$ (initial) and $36 \mathrm{~h}$ showed different patterns. Notably, transcripts for cx34.3 decreased more than 10-fold after $36 \mathrm{~h}$ in culture (Figure $5 \mathrm{~A}$ or $5 \mathrm{C}$ ), while transcripts for $c x 43.2$ increased after the 36 -h incubation, but this was not significant (Figure 5B or 5D). Transcripts for $c \times 30.9$ and $c \times 44.9$ were very low in the initial sample and did not change after $36 \mathrm{~h}$ culture (data not shown).

\section{In vitro ovarian E2 production}

Medium E2 levels increased in a concentration-dependent manner in response to FSH (culture experiment 1, Figure 6A) and LH (culture experiment 2, Figure 6C). In contrast, IGF1 had no effect on E2 production at any concentration in both experiments (Figure 6B and 6D).

\section{Discussion}

In this study, we have shown that multiple $c x$ gene transcripts, designated $c x 30.9, c x 34.3, c x 43.2$ and $c x 44.9$, are expressed in coho salmon ovaries, have distinct developmental expression patterns, and differ in their hormonal regulation. The sequence homologies, consensus sequences, and predicted topologies of the four deduced proteins are in strong agreement with the predicted structural traits of Cx family proteins [4]. Such multiple expression of $c x$ gene transcripts in the ovary is well known in mammals [9]; however, interrelationships between various $c x$ isoforms to form a connexon and ultimately GJs are poorly understood. GJs are composed of two connexons, both of which are hexamers of $\mathrm{Cx}$ proteins. As most cell types express more than one $c x$ isoform, a connexon could potentially be composed of either one type of $\mathrm{Cx}$ (homomeric) or more than one type of Cx (heteromeric) [44]. When two identical connexons dock, they form a homotypic GJ, while when two different connexons dock, they form a heterotypic GJ [44]. We did not examine the functional aspects of the four different Cx proteins in coho salmon; however, previous studies in two Perciform fishes suggest that heterotypic GJs have much lower functional activity than homotypic GJs $[45,46]$. To determine the compatibility between four different Cx proteins in coho salmon, further analyses using an in vitro cell expression system and dye transfer assay $[47,48]$ will be needed.

Although our phylogenetic analysis showed that $c \times 30.9$ and $c x 44.9$ were classified in the $\beta$ group and $\gamma$ group, respectively, the results of spatiotemporal analyses and hormone effects on these genes were similar. Transcripts for $c \times 30.9$ and $c \times 44.9$ were highly expressed at the PN-stage, however these transcripts decreased dramatically by the LD-stage and remained low thereafter. Further, these genes were expressed in follicle cells (theca and/or granulosa cells) and oocytes only at the PN-stage. These data suggest that GJs composed of $c \times 30.9$ and $c \times 44.9$ could have important roles during early oogenesis and could form GJs between follicle cells and the oocyte, and amongst follicle cells at the PNstage. To date, there are no $c x$ isoforms identified in fishes that show the exact spatiotemporal expression pattern as coho salmon $c x 30.9$ and $c x 44.9$. However, in ayu, two $c x$ isoforms designated $c x 44.1$ and $c x 44.2$, that have the highest homology to coho salmon $c x 44.9$, were similarly expressed at the highest levels during early oogenesis [49], but were only expressed in the oocyte and levels did not decline at more advanced stages of oogenesis as seen in salmon. Although coho salmon $c x 30.9$ and $c x 44.9$ share some similarities to ayu $c \times 44.1$ and $c x 44.2$, the difference in localization of the $c x$ transcripts and the low levels of these two coho salmon $c x$ transcripts during the LD-through MAT- stage suggest they are unlikely to have the same function as the ayu $c x$ genes. 

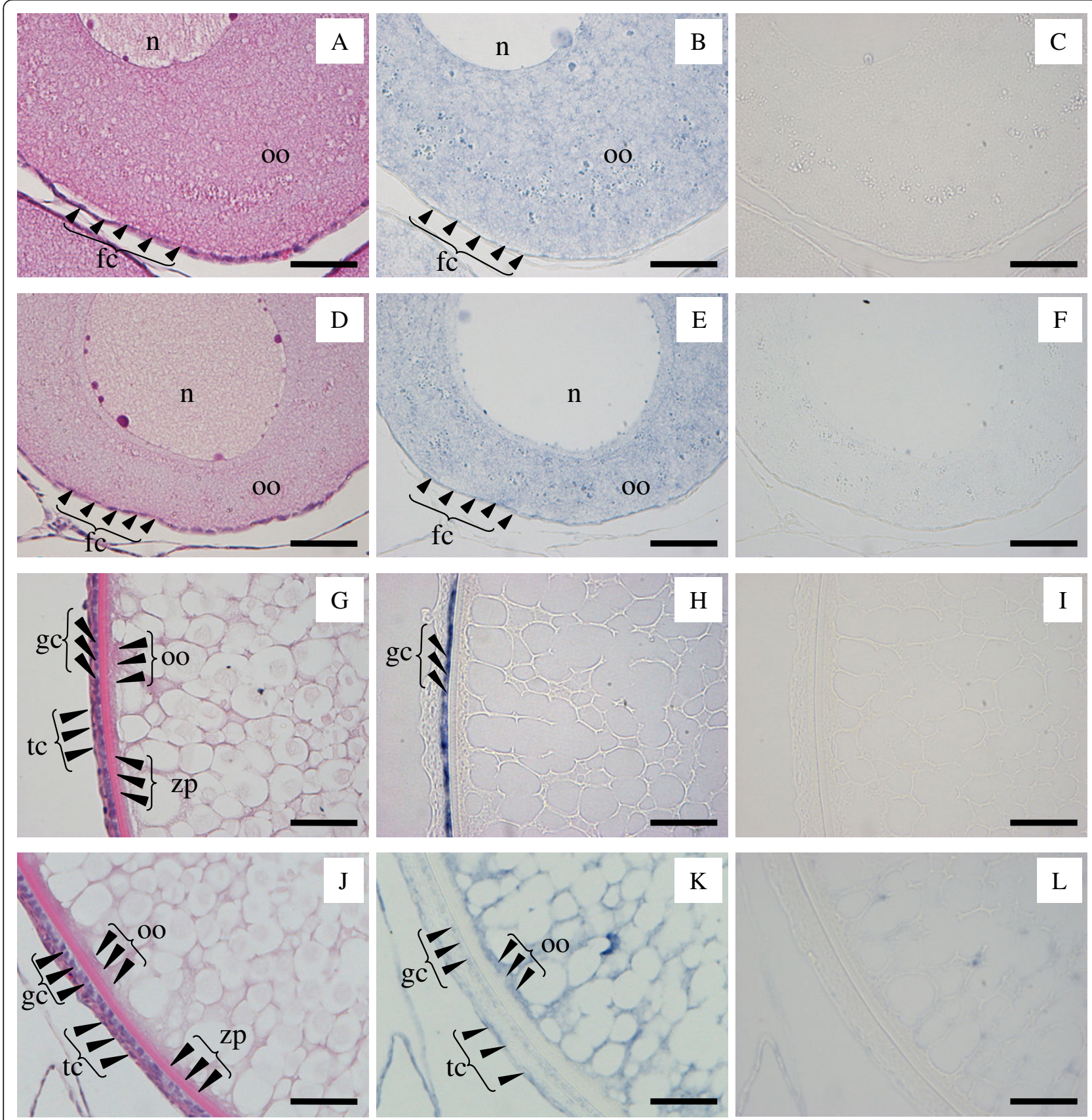

Figure 3 Subfolliclular distribution of mRNAs for $c x 30.9, c x 44.9, c x 34.3$, and $c x 43.2$ in coho salmon ovaries. Perinucleolus (PN)-stage follicles were used for $c \times 30.9$ and $c \times 44.9$ analyses. Lipid droplet (LD)-stage follicles were used for $c \times 34.3$ and $c \times 43.2$ analyses. Sequential sections

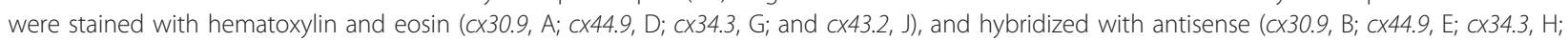
and $c \times 43.2, \mathrm{~K})$ and sense $(c \times 30.9 ; \mathrm{C}, \mathrm{cx44.9;} F, c \times 34.3 ; \mathrm{I}$, and $c \times 43.2 ; \mathrm{L})$ probes. $\mathrm{n}$, nuclear; oo, ooplasm; fc, follicle cells; tc, theca cells; gc, granulosa cells; zp, zona pellucida. Scale bars $=50 \mu \mathrm{m}$.

The gene encoding $c x 34.3$ was classified in the $\alpha$ group in our phylogenetic analysis, began to increase at the CA-stage, reached maximum levels at the mid VITstage and remained high thereafter. Further, ISH revealed that $c x 34.3$ was localized only in granulosa cells. These data suggest that $c \times 34.3$ may compose homotypic GJs, only between granulosa cells, which could have important roles in vitellogenesis and final maturation. In teleosts, it is generally accepted that granulosa cells produce steroid hormones such as E2 and MIH from their respective precursors [50]. In mammals, it is well known that the hormone-producing cells 

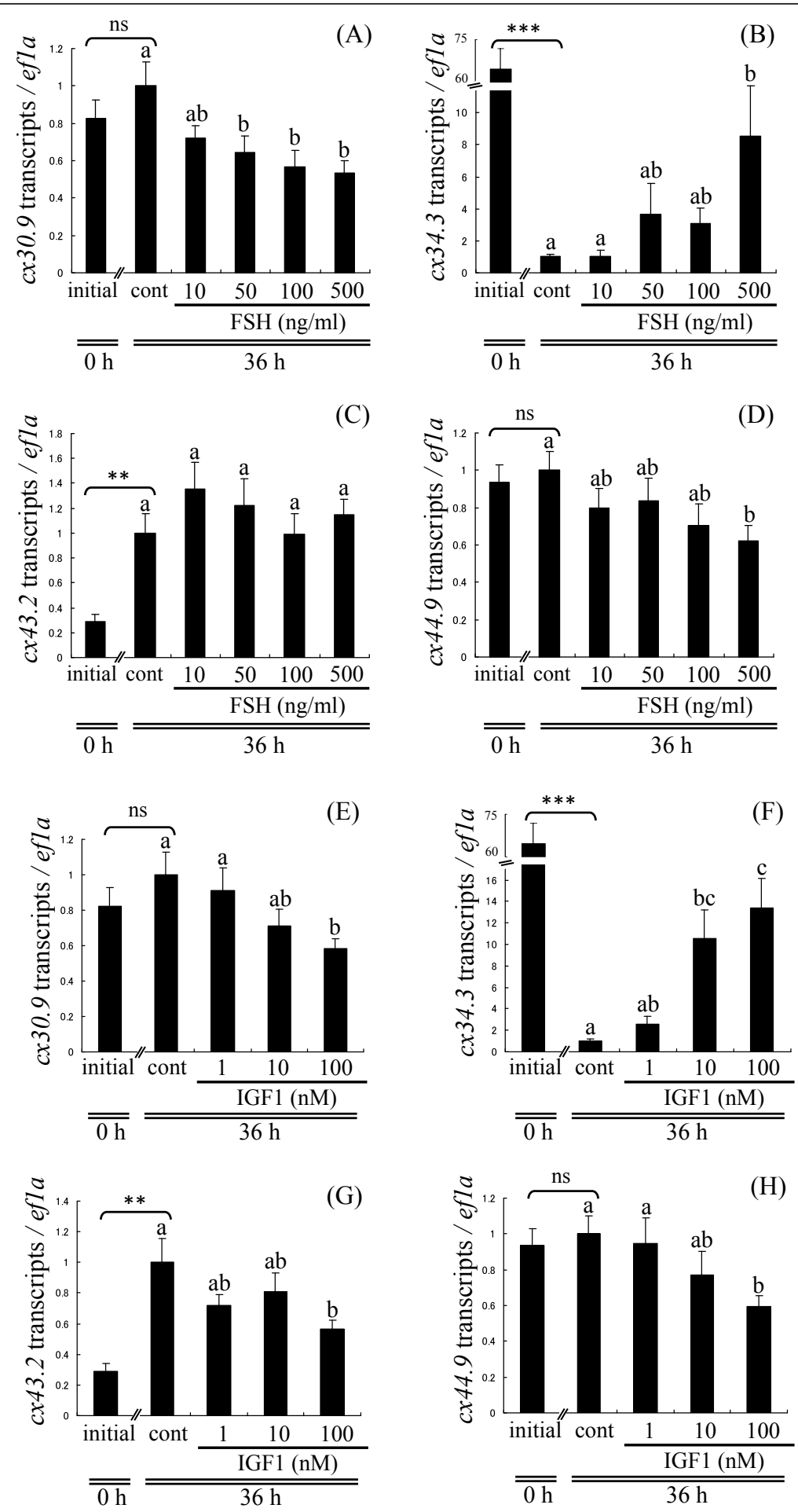

Figure 4 Hormonal regulation of ovarian $c x$ genes in vitro: culture experiment 1. Effects of varying FSH $(10,50,100$, or $500 \mathrm{ng} / \mathrm{ml})$ and IGF1 (1, 10, or 100 nM) concentrations on levels of transcripts for $c \times 30.9$ (A, E), cx34.3 (B, F), cx43.2 (C, G), cx44.9 (D, H) in lipid droplet (LD)-stage follicles. Data are expressed as the mean $\pm \operatorname{SEM}(n=6)$ and presented relative to the expression of controls (cont; Time 36 h, no hormones, set to 1). Bars not sharing the same letter are significantly different $(P<0.05)$. Asterisks denote values that significantly differ between initial (Time 0 , no hormones) and control (cont; Time $36 \mathrm{~h}$, no hormones), ${ }^{* * P}<0.01,{ }^{* *} \mathrm{P}<0.001$. ns, no significant difference. 


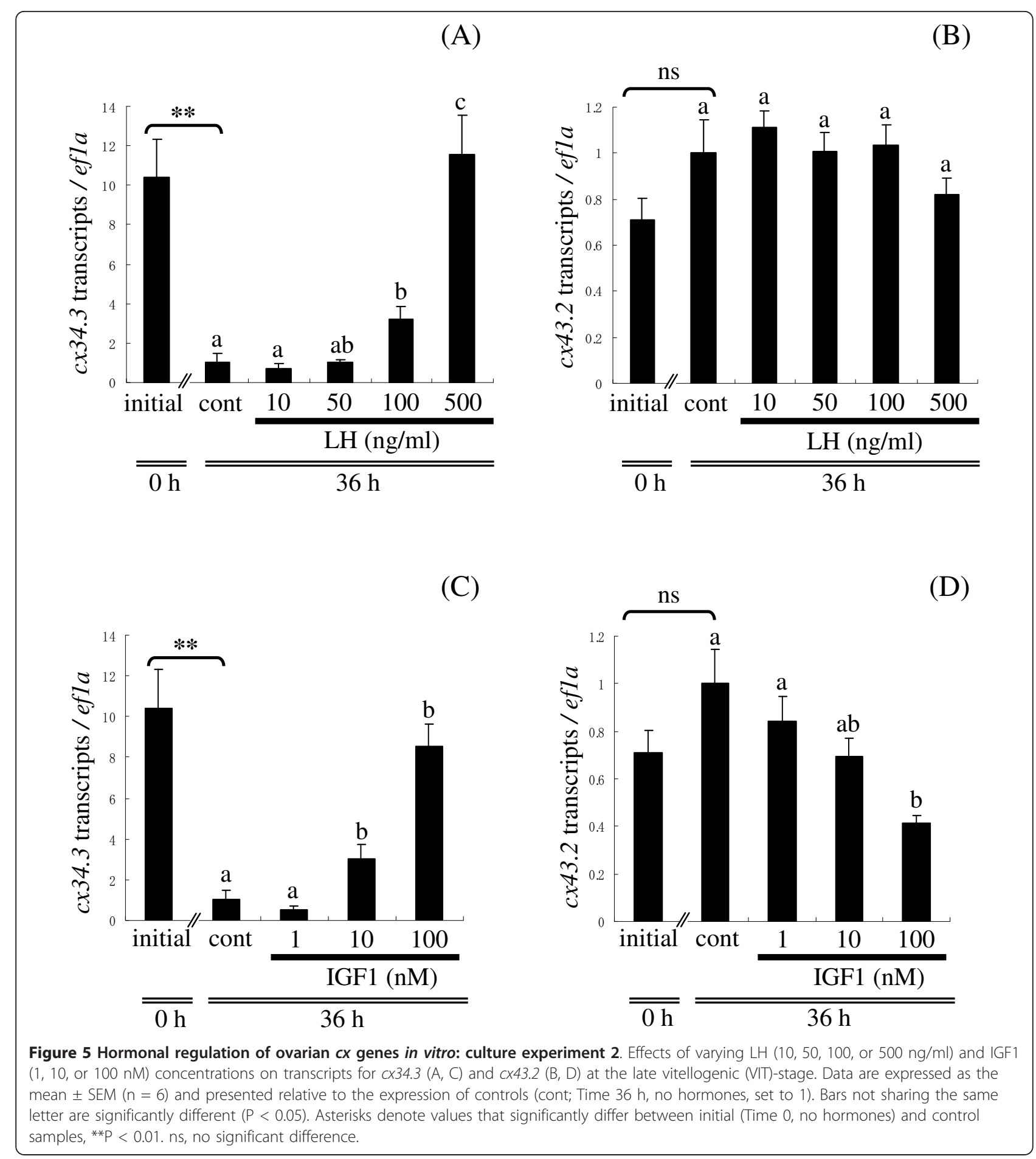

are also connected by functional GJs and are needed for the cells to biosynthesize, store and release hormone effectively [51,52]. Gap junctional communication amongst granulosa cells may have an important role in steroidogenesis [12,53]. Thus, in coho salmon, GJs composed of $c x 34.3$ between granulosa cells may have an important role in ovarian steroidogenesis, but further research will be needed to establish this.

In contrast to $c \times 34.3$, transcripts for $c \times 43.2$ increased later in vitellogenesis, reached maximum levels in the preovulatory follicles, and were localized in both follicle cells (theca and granulosa cells at CA-, LD- and early 


\section{(A)}

(B)
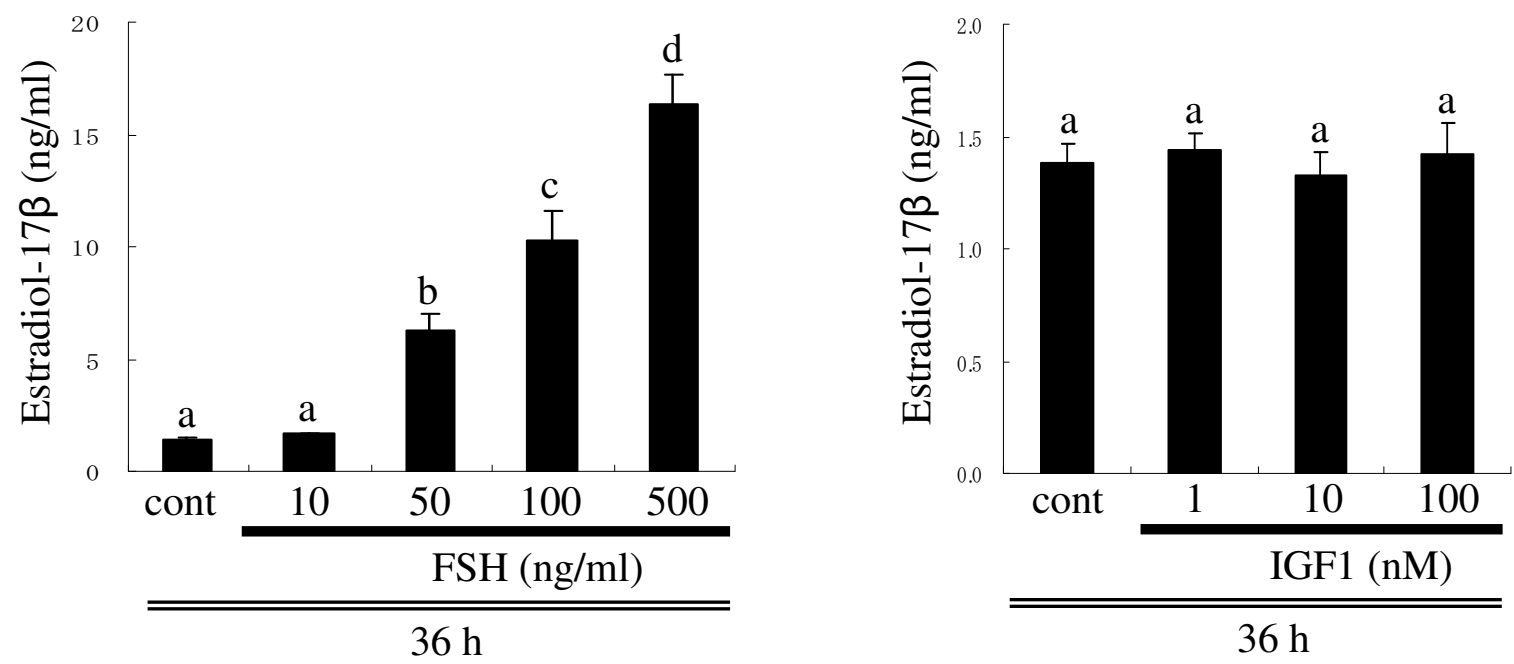

(C)
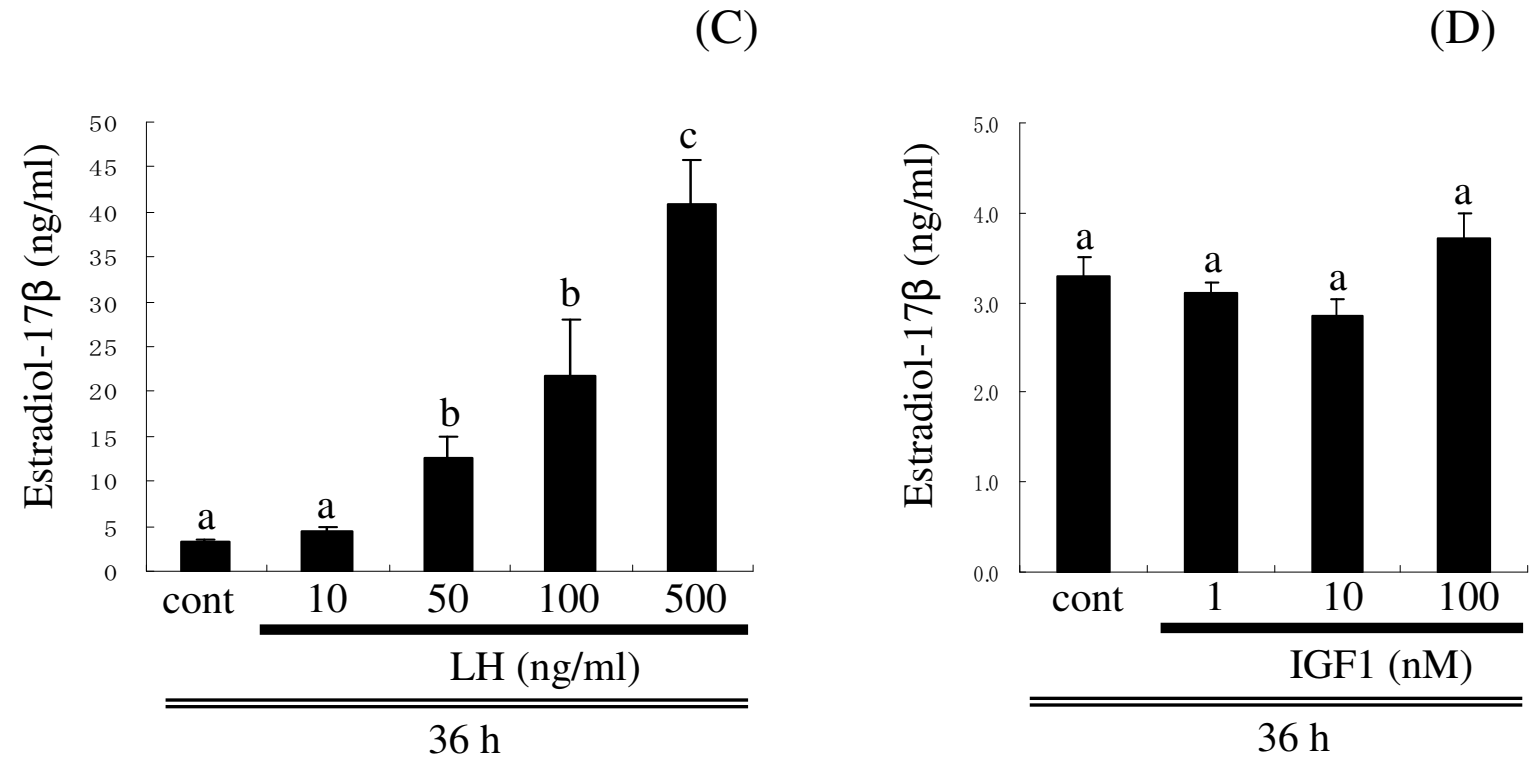

Figure 6 In vitro ovarian E2 production. Effect of varying FSH (A) and IGF1 (B) concentrations on in vitro E2 production by lipid droplet (LD)stage follicles (culture experiment 1) and varying LH (C) and IGF1 (D) concentrations on in vitro E2 production by late vitellogenic (VIT)-stage follicles (culture experiment 2). Incubations were for $36 \mathrm{~h}$. Data are expressed as the mean \pm SEM $(n=6)$. Bars not sharing the same letter are significantly different $(P<0.05)$.

VIT-stages) and oocytes. These data suggest that $c \times 43.2$ could compose homotypic GJs, between the follicle cells and the oocyte, and between the follicle cells, and that GJs formed by $c x 43.2$ may be involved in late vitellogenesis and final maturation. The observed increase in $c x 43.2$ at the MAT-stage was consistent with a previous report of rainbow trout $c \times 43$ [33], a homologue of coho salmon $c x 43.2$. Phylogenetic analysis revealed that coho salmon $c x 43.2$ and trout $c x 43$ were both classified in the $\alpha$ group. The temporal expression pattern and follicular localization of coho salmon $c x 43.2$ showed a similar pattern to that of ayu $c \times 34.9$ [49]. In ayu, $c \times 34.9$ appears to contribute to formation of GJs between the oocyte and the granulosa cells, and may have an important role in transmitting the LH-signal received in the follicle cells to the oocyte via a second messenger such as cAMP during acquisition of OMC $[14,15,49]$. Although we have no empirical data on the function of coho salmon 
$c x 43.2$, it may have a similar role to ayu $c x 34.9$ given the similarity of their spatiotemporal expression patterns.

Hormonal regulation of $c x$ gene transcripts has been reported in several fishes. However, previous studies of the hormonal regulation of ovarian $c x$ gene transcripts mainly focused on MAT-stage follicles [21-25]. To assess hormonal regulation of $c x$ gene transcripts during various stages of oogenesis, we performed two ovarian culture experiments using previtellogenic (LD-stage; culture experiment 1) and late VIT-stage (culture experiment 2) follicles. At the LD-stage, both FSH and IGF1 increased transcript levels for $c \times 34.3$, but decreased transcripts for $c x 30.9$ and $c x 44.9$. In late VIT-stage follicles, LH and IGF1 had a stimulatory effect on transcripts for $c x 34.3$. While LH had no effect on levels of transcripts for $c x 43.2$, IGF1 showed a clear inhibitory effect. These data suggest that gonadotropins and IGF1 regulate ovarian $c x$ trancripts in a $c x$ - and stage-specific manner, and may influence GJ formation and therefore communication within the ovary. Although the stimulatory effect of IGF1 on the number of GJs has been reported in red seabream ovary [12], to our knowledge this is the first report of IGF1 regulation of ovarian $c x$ gene expression. As IGF1 receptors were found in granulosa cells of coho salmon [38], it is possible that IGF1 (either endocrine or paracrine IGF) regulates $c \times 34.3$ gene expression in granulosa cells. The up- and downregulation of specific $c x$ genes by gonadotropins shown in the present study is consistent with previous studies in Atlantic croaker [23-25]. Although the mechanisms of ovarian $c x$ activation by hormones were not addressed in the present study, studies of Atlantic croaker revealed that gonadotopic regulation of $c x$ genes was mediated by the cAMP-protein kinase A transduction pathway $[24,54]$. Obviously, further promoter studies are needed to elucidate the role of second messenger systems or other transcription factors in the regulation of $c x$ gene expression by gonadotropins and IGF1 in the ovary of coho salmon.

Our results show that both FSH and LH, but not IGF1, stimulated in vitro production of ovarian E2, thus we cannot rule out the possibility that the observed effects of gonadotropins were mediated by steroids. In mammals, many studies indicated that steroid hormones regulate $c x$ gene expression [55-57]. For example, in the ovariectomized rat endometrium, a high amount of progesterone in combination with low E2 levels suppressed transcripts for $c x 26$ and $c x 43$, but higher E2 levels had no effect on $c x 26$ expression [57]. In Atlantic croaker, E2 had a biphasic effect on $c x 32.7$ [25]. At a low concentration, E2 had no effect on $c \times 32.7$ transcripts, but at high concentrations, it inhibited expression [25]. Thus, E2 appears to regulate $c x$ gene expression in teleosts as well. To clarify the involvement of steroid hormones in the regulation of ovarian $c x$ gene expression, further in vitro culture experiments using inhibitors of E2 synthesis or other steroid hormones such as progesterone and testosterone will be needed.

The developmental patterns and hormonal regulation of $c x$ gene expression were consistent with what is known about plasma levels of FSH, LH, and IGF1 during the reproductive cycle of salmon. For example, transcripts for $c x 34.3$ began to increase at the CA- to LDstage and peaked during mid vitellogenesis. This expression profile is consistent with plasma FSH [26,27] and IGF1 profiles in female coho salmon [27,29] and our results indicate that both of these hormones stimulate ovarian cx34.3 expression in vitro. Plasma levels of FSH [26] and IGF1 [28] in salmon decrease at final oocyte maturation, while plasma LH levels increase during this period [26]. Our results indicate that at this stage, LH increased expression of $c x 34.3$. Taken together, high expression of $c x 34.3$ at the LD - to VIT-stage could be regulated by FSH and IGF1, and then at the MAT-stage, LH could maintain high expression of $c x 34.3$. Interestingly, incubation of LD-stage ovarian follicles in control medium without any hormones for 36 h reduced transcripts for $c x 34.3$ more than 64 -fold relative to the initial levels, and this reduction did not fully recover by incubation with FSH and IGF1, even at the highest hormone concentrations. These data suggest that $c \times 34.3$ is regulated by a number of factors in vivo, including FSH and IGF1, and perhaps other unidentified factors at this stage. Since we did not test any combination of hormones in our experiments, we do not yet know if there are additive or synergistic effects of gonadotropins and IGF1.

In contrast to $c x 34.3, \mathrm{FSH}$ and $\mathrm{LH}$ did not have any effect on levels of $c x 43.2$ transcripts. It was somewhat surprising that $\mathrm{LH}$, in particular, did not show any effect on this gene, despite the expression profile of $c \times 43.2$ being similar to that of plasma LH [26]. Although the existence of other regulators of $c x 43.2$ remains a possibility, one potential scenario to explain ovarian $c \times 43.2$ regulation in coho salmon is inhibitory regulation by IGF1. Both culture experiments revealed that only IGF1 inhibited $c x 43.2$ expression. In salmon, plasma IGF1 levels typically increase during early secondary oocyte growth and decrease at the preovulatory stage [27-29]. Temporal expression analyses revealed that transcripts for $c \times 43.2$ were relatively low until the mid VIT-stage, but significantly increased by the MAT-stage. Thus, IGF1 may inhibit $c x 43.2$ expression through most of oogenesis, and the natural decrease in plasma IGF1 prior to final oocyte maturation may induce elevations in cx43.2 expression. Notably, incubation of ovarian follicles in control medium for $36 \mathrm{~h}$ induced more than a 3 -fold increase in this gene relative to initial samples in 
culture experiment 1 . These in vitro data as well as the developmental pattern in vivo support the idea that in vivo factors negatively regulate $c \times 43.2$ expression, and that one of these factors may be IGF1.

At the LD-stage, transcripts for $c \times 30.9$ and $c \times 44.9$ were down-regulated by both FSH and IGF1 in vitro. Temporal expression analyses of these transcripts revealed that their expression decreased at the LD-stage. Thus, the decrease in these transcripts in our acrossstage comparison could be due to increases in FSH $[26,27]$ and IGF1 $[27,29]$ that occur naturally in this species. Further research will be needed to identify factors that may up-regulate $c x 30.9$ and $c x 44.9$ gene expression during early oogenesis.

\section{Conclusion}

In this study, we show that at least four different $c x$ genes, designated $c x 30.9, c x 34.3, c x 43.2$, and $c x 44.9$, are expressed in the coho salmon ovarian follicle. Transcripts for $c \times 30.9$ and $c \times 44.9$ were highly expressed in $\mathrm{PN}$-stage follicles and localized to the follicle cells and oocytes. Transcripts for $c x 34.3$ were highly expressed at the mid VIT-stage and were localized only to granulosa cells. Transcripts for $c x 43.2$ were highly expressed at the MAT-stage in theca and granulosa cells, and oocytes. Thus, the results of spatiotemporal analyses revealed that $c x 30.9, c x 34.3, c x 43.2$, and $c x 44.9$ were under ovarian stage and cell-type specific control during oogenesis. Further, FSH, LH, and IGF1 differentially regulated these ovarian $c x$ gene transcripts in vitro. To our knowledge, this is the first report of IGF1 regulation of ovarian $c x$ gene expression. These data indicate that the differences in spatiotemporal expression profiles and hormone-mediated regulation of these four $c x$ transcripts may be related to the function of ovarian GJs during different stages of ovarian cellular differentiation. Future studies on the cell-cell communication permitted by GJs formed by these Cx proteins will be important to understanding development of the ovarian follicle in teleosts.

\section{Acknowledgements}

We thank J.T. Dickey (University of Washington) for his assistance with this work. This research was funded partially by NOAA Fisheries and by National Research Initiative Competitive Grant no. 2007-35203-18088 from the USDA National Institute of Food and Agriculture.

\section{Author details}

${ }^{1}$ School of Aquatic \& Fishery Sciences, University of Washington, Seattle, WA 98195, USA. Northwest Fisheries Science Center, NOAA Fisheries, Seattle, WA 98112, USA.

\section{Authors' contributions}

YY participated in the study design, execution of experiments, data analysis and interpretation, and drafted the manuscript. MAM participated in the execution of experiments, performed the E2 assay, and participated in data analyses. JAL participated in study design, execution of experiments, and interpretation of data. PS acquired funding for the work, participated in study design, and assisted with data analysis and interpretation. All the authors read, edited, and approved the final manuscript.

\section{Competing interests}

The authors declare that they have no competing interests.

Received: 29 December 2010 Accepted: 19 April 2011

Published: 19 April 2011

\section{References}

1. Eppig JJ: Intercommunication between mammalian oocytes and companion somatic cells. Bioessays 1991, 13:569-574.

2. Gilchrist RB, Ritter LJ, Armstrong DT: Oocyte-somatic cell interactions during follicle development in mammals. Anim Reprod Sci 2004 82-83:431-446.

3. Kumar NM, Gilula NB: The gap junction communication channel. Cell 1996, 84:381-388.

4. Beyer EC, Paul DL, Goodenough DA: Connexin family of gap junction proteins. J Membrane Biol 1990, 116:187-194.

5. Bruzzone R, White TW, Paul DL: Connections with connexins: the molecular basis of direct intercellular signaling. Eur J Biochem 1996, 238:1-27.

6. Grazul-Bilska AT, Reynolds LP, Redmer DA: Gap junctions in the ovaries. Biol Reprod 1997, 57:947-957.

7. Kidder GM, Mhawi AA: Gap junctions and ovarian folliculogenesis. Reproduction 2002, 123:613-620.

8. Dekel N: Cellular, biochemical and molecular mechanisms regulating oocyte maturation. Mol Cell Endocrinol 2005, 234:19-25.

9. Gershon E, Plaks V, Dekel N: Gap junctions in the ovary: expression, localization and function. Mol Cell Endocrinol 2008, 282:18-25.

10. Patiño R, Sullivan CV: Ovarian follicle growth, maturation, and ovulation in teleost fish. Fish Physiol Biochem 2002, 26:57-70.

11. York WS, Patiño R, Thomas P: Ultrastructural changes in follicle cell-oocyte associations during development and maturation of the ovarian follicle in Atlantic croaker. Gen Comp Endocrinol 1993, 92:402-418.

12. Patiño $\mathrm{R}$, Kagawa $\mathrm{H}$ : Regulation of gap junctions and oocyte maturational competence by gonadotropin and insulin-like growth factor-I in ovarian follicles of red seabream. Gen Comp Endocrinol 1999, 115:454-462.

13. Bolamba D, Patiño R, Yoshizaki G, Thomas P: Changes in homologous and heterologous gap junction contacts during maturation-inducing hormone-dependent meiotic resumption in ovarian follicles of Atlantic croaker. Gen Comp Endocrinol 2003, 131:291-295

14. Yamamoto $Y$, Yoshizaki G, Takeuchi T, Soyano K, Patiño R: Role of gap junctions and protein kinase A during the development of oocyte maturational competence in Ayu (Plecoglossus altivelis). Gen Comp Endocrinol 2008, 155:789-795.

15. Yamamoto $Y$, Yoshizaki G: Heterologous gap junctions between granulosa cells and oocytes in ayu (Plecoglossus altivelis): formation and role during luteinizing hormone-dependent acquisition of oocyte maturational competence. J Reprod Dev 2008, 54:1-5.

16. Söhl G, Willecke K: An update on connexin genes and their nomenclature in mouse and man. Cell Commun Adhes 2003, 10:173-180.

17. Eastman SD, Chen THP, Falk MM, Mendelson TC, lovine MK: Phylogenetic analysis of three complete gap junction gene families reveals lineagespecific duplications and highly supported gene classes. Genomics 2006, 87:265-274.

18. Oyamada M, Oyamada Y, Takamatsu T: Regulation of connexin expression Biochim Biophys Acta Biomembr 2005, 1719:6-23.

19. Sommersberg B, Bulling A, Salzer U, Fröhlich U, Garfield RE: Gap junction communication and connexin 43 gene expression in a rat granulosa cell line: regulation by follicle-stimulating hormone. Biol Reprod 2000, 63:1661-1668

20. Granot I, Dekel N: Phosphorylation and expression of connexin-43 ovarian gap junction protein are regulated by luteinizing hormone. J Biol Chem 1994, 269:30502-30509.

21. Choi CY, Takashima F: Molecular cloning and hormonal control in the ovary of connexin 31.5 mRNA and correlation with the appearance of oocyte maturational competence in red seabream. J Exp Biol 2000, 203:3299-3306. 
22. Choi CY, Takemura A: Molecular cloning and expression of connexin 32.3 CDNA in the ovary from the red seabream (Pagrus major). Comp Biochem Physiol B 2001, 129:767-775.

23. Yoshizaki G, Patiño $R$, Thomas $P$ : Connexin messenger ribonucleic acids in the ovary of Atlantic croaker: molecular cloning and characterization, hormonal control, and correlation with appearance of oocyte maturational competence. Biol Reprod 1994, 51:493-503.

24. Chang X, Patiño R, Thomas P, Yoshizaki G: Developmental and protein kinase-dependent regulation of ovarian connexin mRNA and oocyte maturational competence in Atlantic croaker. Gen Comp Endocrinol 1999, 114:330-339.

25. Chang X, Patiño R, Yoshizaki G, Thomas P, Lee VH: Hormonal regulation and cellular distribution of connexin 32.2 and connexin 32.7 RNAs in the ovary of Atlantic croaker. Gen Comp Endocrinol 2000, 120:146-156.

26. Swanson P: Salmon gonadotropins: reconciling old and new ideas. In Proceedings of the Fourth International Symposium on the Reproductive Physiology of Fish: 7-12 July 1996; Sheffield, UK Edited by: Scott AP, Sumpter JP, Kime DE, Rolfe MS 1996, 2-7.

27. Campbell B, Dickey J, Beckman B, Young G, Pierce A, Fukada H, Swanson P: Previtellogenic oocyte growth in salmon: relationships among body growth, plasma insulin-like growth factor-1, estradiol-17beta, folliclestimulating hormone and expression of ovarian genes for insulin-like growth factors, steroidogenic-acute regulatory protein and receptors for gonadotropins, growth hormone, and somatolactin. Biol Reprod 2006, 75:34-44.

28. Onuma TA, Makino K, Katsumata H, Beckman BR, Ban M, Ando $H$, Fukuwaka M, Azumaya T, Swanson P, Urano A: Changes in the plasma levels of insulin-like growth factor-I from the onset of spawning migration through upstream migration in chum salmon. Gen Comp Endocrinol 2010, 165:237-243.

29. Yamamoto Y, Luckenbach JA, Goetz FW, Young G, Swanson P: Disruption of the salmon reproductive endocrine axis through prolonged nutritional stress: Changes in circulating hormone levels and transcripts for ovarian genes involved in steroidogenesis and apoptosis. Gen Comp Endocrinol 2011.

30. Nagahama $Y$ : The functional morphology of teleost gonads. In Fish Physiology. Volume IX, Reproduction. Part A, Endocrine Tissue and Hormones. Edited by: Hoar WS, Randall DJ, Donaldson EM. New York: Academic Press; 1983:223-275

31. Luckenbach JA, lliev DB, Goetz FW, Swanson P: Identification of differentially expressed ovarian genes during primary and early secondary oocyte growth in coho salmon, Oncorhynchus kisutch. Reprod Biol Endocrinol 2008, 6:2.

32. DFCl R. trout gene index database. [http://compbio.dfci.harvard.edu/cgibin/tgi/gimain.pl?gudb=r_trout].

33. Bobe J, Nguyen T, Jalabert B: Targeted gene expression profiling in the rainbow trout (Oncorhynchus mykiss) ovary during maturational competence acquisition and oocyte maturation. Biol Reprod 2004, 71:73-82.

34. Luckenbach JA, Dickey JT, Swanson P: Follicle-stimulating hormone regulation of ovarian transcripts for steroidogenesis-related proteins and cell survival, growth and differentiation factors in vitro during early secondary oocyte growth in coho salmon. Gen Comp Endocrinol 2011, 171:52-63.

35. Planas JV, Athos J, Goetz FW, Swanson P: Regulation of ovarian steroidogenesis in vitro by follicle-stimulating hormone and luteinizing hormone during sexual maturation in salmonid fish. Biol Reprod 2000 62:1262-1269.

36. Swanson P, Suzuki K, Kawauchi H, Dickhoff WW: Isolation and characterization of two coho salmon gonadotropins, GTH I and GTH II. Biol Reprod 1991, 44:29-38.

37. Swanson P, Bernard M, Nozaki M, Suzuki K, Kawauchi H, Dickhoff WW: Gonadotropins I and II in juvenile coho salmon. Fish Physiol Biochem 1989, 7:169-176.

38. Maestro M, Planas JV, Moriyama S, Gutiérrez J, Planas J, Swanson P: Ovarian receptors for insulin and insulin-like growth factor I (IGF-I) and effects of IGF-I on steroid production by isolated follicular layers of the preovulatory coho salmon ovarian follicle. Gen Comp Endocrinol 1997, 106:189-201.

39. Sower SA, Schreck CB: Steroid and thyroid hormones during sexual maturation of coho salmon (Oncorhynchus kisutch) in seawater or fresh water. Gen Comp Endocrinol 1982, 47:42-53.
40. Beyer EC, Paul DL, Goodenough DA: Connexin43: A protein from rat heart homologous to a gap junction protein from liver. J Cell Biol 1987, 105:2621-2629.

41. NCBI BLAST. [http://blast.ncbi.nlm.nih.gov/].

42. Larkin MA, Blackshields G, Brown NP, Chenna R, McGettigan PA, McWilliam H, Valentin F, Wallace IM, Wilm A, Lopez R, Thompson JD, Gibson TJ, Higgins DG: Clustal W and Clustal X version 2.0. Bioinformatics 2007, 23:2947-2948.

43. Saitou N, Nei M: The neighbor-joining method: a new method for reconstructing phylogenetic trees. Mol Biol Evol 1987, 4:406-425.

44. Corttrell GT, Burt JM: Functional consequences of heterogeneous gap junction channel formation and its influence in health and disease. Biochim Biophys Acta Biomembr 2005, 1711:126-141.

45. Bruzzone R, White TW, Yoshizaki G, Patiño R, Paul DL: Intercellular channels in teleosts: functional characterization of two connexins from Atlantic croaker. FEBS Lett 1995, 358:301-304.

46. O'Brien J, Bruzzone R, White TW, Al-Ubaidi MR, Ripps H: Cloning and expression of two related connexins from the perch retina define a distinct subgroup of the connexin family. J Neurosci 1998, 18:7625-7637.

47. Meda P: Assaying the molecular permeability of connexin channels. In Connexin Methods and Protocols. Edited by: Bruzzone R, Giaume C. New Jersey: Humana Press; 2001:201-224, [Walker JM (Series Editor): Methods and Molecular Biology, vol 154.].

48. Skerrett IM, Merritt M, Zhou L, Zhu H, Cao F, Smith JF, Nicholson BJ: Applying the Xenopus oocyte expression system to the analysis of gap junction proteins. In Connexin Methods and Protocols. Edited by: Bruzzone R, Giaume C. New Jersey: Humana Press; 2001:225-249, [Walker JM (Series Editor): Methods and Molecular Biology, vol 154.].

49. Yamamoto Y, Yoshizaki G, Takeuchi T, Soyano K, Itoh F, Patiño R: Differential expression and localization of four connexins in the ovary of the ayu (Plecoglossus altivelis). Mol Reprod Dev 2007, 74:1113-1123.

50. Nagahama Y: Endocrine regulation of gametogenesis in fish. Int J Dev Biol 1994, 38:217-229.

51. Serre-Beinier V, Mas C, Calabrese A, Caton D, Bauquis J, Caille D, Charollais A, Cirulli V, Meda P: Connexins and secretion. Biol Cell 2002, 94:477-492.

52. Michon L, Nlend RN, Bavamian S, Bischoff L, Boucard N, Caille D, Cancela J, Charollais A, Charpantier E, Klee P, Peyrou M, Populaire C, Zulianello L, Meda P: Involvement of gap junctional communication in secretion. Biochim Biophys Acta Biomembr 2005, 1719:82-101.

53. Ke FC, Fang SH, Lee MT, Sheu SY, Lai SY, Chen YJ, Huang FL, Wang PS, Stocco DM, Hwang JJ: Lindane, a gap junction blocker, suppresses FSH and transforming growth factor $\beta 1$-induced connexin43 gap junction formation and steroidogenesis in rat granulosa cells. J Endocrinol 2005, 184:555-566.

54. Yoshizaki G, Jin W, Patiño R, Thomas P, Janecek L: Structural organization of the Atlantic croaker connexin 32.2 gene and its $5^{\prime}$ flanking region. Mar Biotechnol 2000, 2:154-160.

55. Grümmer R, Chwalisz K, Mulholland J, Traub O, Winterhager E: Regulation of connexin 26 and connexin43 expression in rat endometrium by ovarian steroid hormones. Biol Reprod 1994, 51:1109-1116.

56. Risek B, Klier FG, Phillips A, Hahn DW, Gilula NB: Gap junction regulation in the uterus and ovaries of immature rats by estrogen and progesterone. J Cell Sci 1995, 108:1017-1032.

57. Grümmer R, Traub O, Winterhager E: Gap junction connexin genes cx26 and $c \times 43$ are differentially regulated by ovarian steroid hormones in rat endometrium. Endocrinology 1999, 140:2509-2516.

doi:10.1186/1477-7827-9-52

Cite this article as: Yamamoto et al:: The spatiotemporal expression of multiple coho salmon ovarian connexin genes and their hormonal regulation in vitro during oogenesis. Reproductive Biology and Endocrinology 2011 9:52. 